\title{
FOLYAMATOK ÜTEMEZÉSE
}

\author{
Ekárt Anikó \& Péter István
}

\section{Kivonat}

\begin{abstract}
A dolgozat célja egy olyan programcsomag (NONLIN) kifejlesztése amely lehetővé teszi adott folyamatok idóbeli beosztását doméniumtól független módon. A formalizmus magját Tate nemlineáris, hierarchikus ütemezője [1] képezi. A program feladata egy vagy több cél elérésére szolgáló ütemezési terv létrehozása. A program a Golden Common Lisp Objektum Orientált változatában készült. A Tate irányított feltételei mellett bevezettük a nem irányitott feltételeket is, amelyeket az ütemező nem próbál elérni az ütemezési terv bỏvítésének befejezése elött. A NONLIN és környezetének hasznosságát néhány gyakorlati alkalmazás segítségével támasztottuk alá.
\end{abstract}




\section{A NONLIN RENDSZER ISMERTETÉSE}

A dolgozat célja több doméniumban elöforduló folyamatok időbeli ütemezése. Az ütemezést a NONLIN nevü Objektum Orientált Golden Common LISP-ben megírt program segítségével végezzük.

A NONLIN nevứ program egy ütemezési tervet hoz létre egy bizonyos doméniumban adott cél (célok) elérésére. A NONLIN doméniumtól független folyamat-ütemező és nem kizárólag csak egyes doméniumokra alkalmas. A program elönye, hogy a szükséges információt a doméniumról egy hierarchikus Task Formalizmus segítségével specifikáljuk. A Task Formalizmus felbontja a doméniumot célokra, tevékenységekre, operátorokra és logikai predikátumokra. A feladat doméniumát különböző elvontsági szinteken lehet definiálni a Task Formalizmus séma-meghatározásai segítségével. A NONLIN úgy használja fel az elvontsági szinteket, hogy a tervet előbb magasabb szintú operátorokból képezi, melyeket késóbb alacsonyabb szintú operátorokra bont fel. A legalacsonyabb szintú operátorok primitívák, ezek nem bonthatók tovább.

A NONLIN készíthet ütemezési tervet olyan feladatok számára is, ahol több egymást befolyásoló cél lineáris ütemezése nem felelne meg. Ahhoz, hogy nemlineárisan ütemezhessen, a NONLIN az ütemezési terveket egy részlegesen rendezett gráfban tárolja. Az ütemező egy olyan stratégiát alkalmaz amely elhalasztja az események rendezését mindaddig amíg ez szükségessé nem válik. Egy ilyen rendezés akkor lesz szükséges, amikor egy tevékenység ki kell értékelje egy másik tevékenység prekondicióját vagy több tevékenység eredménye egymásratevődik. (pl. amikor egy tevékenység egy másik tevékenység prekondicióját tagadja). Az ütemezés eredménye egy teljesen rendezett ütemezési terv (egyike a lehetséges terveknek).

NONLIN képes backtraking-re, ezáltal lehetővé válik más lehetséges ütemezési tervek elkészítése is, ugyanakkor képes a holtpontokból való kijutásra is. A választási pontokat egy veremben tárolja minden alkalommal amikor több változat közül választ. A választási pontok és környezetek backtracking-je depth-first módszerrel történik.

A kontroll ciklus a gráf aktuális csomópontjainak kibővítéséből és a tevékenységek közti kapcsolatok vizsgálatából áll. Ez a müvelet addig folytatódik, amíg a gráf teljesen ki lesz bỏvítve és elkészül az ütemezési terv. Amikor az aktuális terv nem bővíthető tovább vagy egy kölcsönhatás nem javítható, az ütemezỏ áttér egy másik, a veremben található választási pontra (ha lehetséges) és folytatja az ütemezési terv készítését. 


\section{A TASK FORMALIZMUS}

A Task Formalizmus (TF) Tate mechanizmusa [1] alapján határozza meg a doménium operátorait és tevékenységeit.

A feladat doméniumának modellezésekor használhatunk magasabb és alacsonyabb szintứ operátorokat. Az ütemezö a tervet úgy fejleszti ki, hogy azokat az operátorokat veszi figyelembe, amelyek megfelelnek a magasabb szintủ céloknak. Ezeket a magasabb szintủ operátorokat az ütemező később helyettesíti alacsonyabb szintü operátorokkal. A doménium felbontása által az ütemezö hatékonyabb lesz. $\mathbf{A z}$ operátorok felbontását az adott feladat TF definiciói által specifikáljuk. A felbontás tetszöleges mélységig történhet.

A sémák a következő mezőkböl állnak:

- típus: operátor vagy tevékenység

- név

- teen dó: egy cél kibővítésekor NONLIN ezt a mezőt próbálja egyeztetni a céllal

- bóvítés: részlegesen rendezett lépés-lista

- rendezések: a bövítés lépései közti rendezések

- feltételek: meghatározzák hogy egy használható séma (amely egyeztethető az aktuális céllal) instanciálható-e

- hatások: a tevékenységek hatásai

- változók: a séma definíciójában használt változók listája

A séma definiálására használt szintakszist egy példával illusztráljuk:

( opschema makeclear

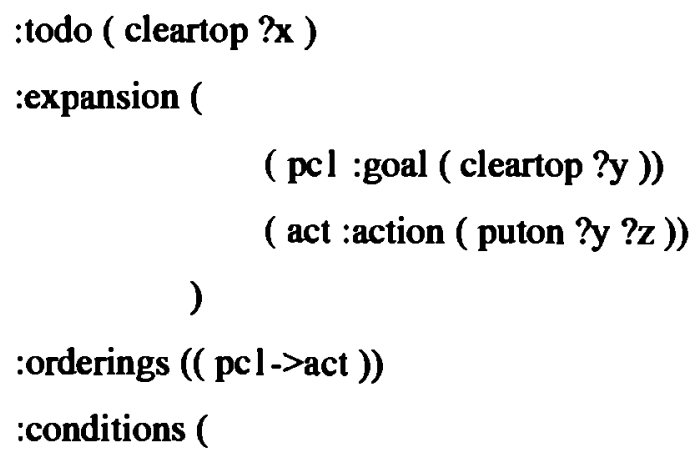




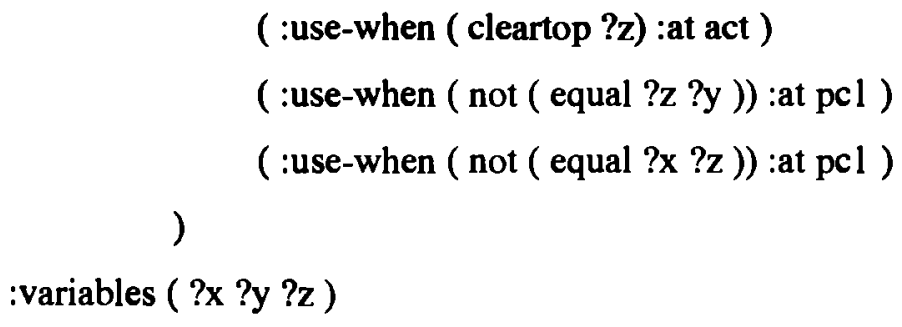

A NONLIN bemenő adatai:

- a doménium operátorainak és tevékenységeinek task formalizmusbeli definiciója

- axiomák listája

- a modelált világ kezdeti helyzetét leíró tények listája

- célok listája

A NONLIN kimenete egy ütemterv (alternatív tervek is generálhatók).

\section{GYAKORLATI ALKALMAZÁSOK}

A NONLIN programcsomagot a következő feladatok megoldására használtuk: projekt management problémák , egy ház felépítéséhez szükséges mưveletek ütemezése, órarendkészítés, gyártási folyamatok ütemezése. A különböző doméniumok modellezése nagyon egyszerünek bizonyult.

\section{IRODALOM}

[1] Austin Tate: “Project Planning Using a Hierarchic Non-Linear Planner", Research Report, Department of Artificial Intelligence, University of Edinburgh, 1994

[2] A. Meyer: $\quad$ "Constraint Based Process Planning”

Research Report, Department of Artificial Intelligence, Carnegie Mellon University, 1992

Ekárt Anikó \& Péter István/ VI. éves egyetemi hallgatók Kolozsvári Mứszaki Egyetem, Számítástecnika tanszék/Baritiu u. 3

Tel. 194684 